\title{
OPTIMIZATION OF PROCESS PARAMETERS DURING END MILLING AND PREDICTION OF WORK PIECE TEMPERATURE RISE
}

\begin{abstract}
During the machining processes, heat gets generated as a result of plastic deformation of metal and friction along the tool-chip and tool-work piece interface. In materials having high thermal conductivity, like aluminium alloys, large amount of this heat is absorbed by the work piece. This results in the rise in the temperature of the work piece, which may lead to dimensional inaccuracies, surface damage and deformation. So, it is needed to control rise in the temperature of the work piece. This paper focuses on the measurement, analysis and prediction of work piece temperature rise during the dry end milling operation of $\mathrm{Al} \mathrm{6063.} \mathrm{The} \mathrm{control} \mathrm{factors} \mathrm{used} \mathrm{for}$ experimentation were number of flutes, spindle speed, depth of cut and feed rate. The Taguchi method was employed for the planning of experimentation and $L_{18}$ orthogonal array was selected. The temperature rise of the work piece was measured with the help of K-type thermocouple embedded in the work piece. Signal to noise $(\mathrm{S} / \mathrm{N})$ ratio analysis was carried out using the lower-the-better quality characteristics. Depth of cut was identified as the most significant factor affecting the work piece temperature rise, followed by spindle speed. Analysis of variance (ANOVA) was employed to find out the significant parameters affecting the work piece temperature rise. ANOVA results were found to be in line with the S/N ratio analysis. Regression analysis was used for developing empirical equation of temperature rise. The temperature rise of the work piece was calculated using the regression equation and was found to be in good agreement with the measured values. Finally, confirmation tests were carried out to verify the results obtained. From the confirmation test it was found that the Taguchi method is an effective method to determine optimised parameters for minimization of work piece temperature.
\end{abstract}

\footnotetext{
${ }^{1}$ Research Scholar, Bapurao Deshmukh College of Engineering, RSTMU, Nagpur and Mechanical Engineering Dept, Sandip Institute of Engineering \& Management, Savitribai Phule Pune University, India.Email: niteen.bhirud@siem.org.in

${ }^{2}$ Mechanical Engineering Dept, Bapurao Deshmukh College of Engineering, RSTMU, Nagpur, India.Email:wsbdcoe@rediffmail.com
} 


\section{Introduction}

Modern machining processes are facing continuous pressures of cost reductions and quality improvements. So, the industries are always searching for the ways to reduce the production costs without compromising on the quality of the end product. To achieve these goals, improvement in the overall performance of cutting operations is required. End milling is one of the most versatile machining operations in industries. In the case of end milling operations, metal is usually removed from a work piece by a multiple point cutting tool. The process of end milling is employed in aerospace and automotive industries for making deep slots, profile recesses, steps etc. [1]. End mills are those tools which have cutting teeth at one end, as well as on the sides. End mills can be used on horizontal milling machine, but it is recommended to use them on vertical milling machine. Their diameter varies from about $3 \mathrm{~mm}$ to $50 \mathrm{~mm}$. They are usually made of high speed steel (HSS) or carbide, and have one or more flutes.

The process of metal cutting is a complex thermo-mechanical phenomenon. During the machining processes, heat gets generated as a result of plastic deformation of metal and friction along the tool-chip and tool-work piece interface. The complexity of machining mechanics makes it difficult to predict the intensity and distribution of heat. The complex coupling between plastic deformation and temperature fields is an area of research for many years. The plastic deformation of metals during machining is concentrated in a narrow zone and thus very high temperature is expected in this region. The maximum temperature occurs at the tool-chip interface. The tool-wear rate and fracture considerably increase at higher temperatures thereby reducing the tool life. High cutting temperature is harmful in numerous respects. Therefore, it is needed to decrease the cutting temperature as much as possible. This can be achieved by several ways like:

- correct choice of material and geometry of the tool(s),

- the most favourable choice of cutting speed and feed combination without reducing material removal rate,

- appropriate choice and use of cutting fluid,

- application of special method, if necessary and practicable.

Cutting fluids are widely used during machining to take away the heat generated; getting better tool life, for superior surface finish and dimensional accuracies; to reduce the possibilities of built-up edge development [2]. The selection and use of proper cutting fluids is the key for the same. But, the use of the cutting fluids is restricted because of several environmental, economical and health issues. Also, the expenses for cooling and lubrication have reached to $16.9 \%$ of the entire manufacturing expenses. Costs of procurement, care and disposal of cutting fluids are two times more than tooling costs [3].

Some of the alternative techniques, which can reduce or eliminate the use of the cutting fluids, are minimum quantity lubrication (MQL), cryogenic cooling and dry cutting [4]. In MQL, a small amount of air-cutting fluid blend, called 
aerosol, is fed onto the machining zone. As compared to dry machining, MQL improves tool life and quality of the machined parts [5]. The cryogenic machining uses coolants in the form liquefied gases. Each of these techniques has advantages and limitations [4]. MQL shows good thermal stability and lubrication effects, but poor cooling capability. The cutting fluids are not eliminated completely in MQL. Cryogenic cooling is environment friendly but, results in changes in the properties of tool and work piece materials. In dry cutting the use of the cutting fluids is completely eliminated, thus it is an environment-friendly technique [2, 4]. Due to certain advantages and limitations of each of these cooling techniques, the choice of the technique is dependent on several economical, ecological factors. In dry cutting, as the cutting fluids are completely eliminated, thus the dry cutting is environment-friendly, economical and healthy for the operators as compared to the flood cooling. Though MQL reduces the use of cutting fluids drastically, still their use is not completely eliminated. Thus, in the current work, dry machining was adopted.

Higher value of the thermal conductivity of aluminium and its alloys make them the most critical materials with regard to dry machining. In materials having high thermal conductivity, like aluminium alloys, large amount of this heat is absorbed by the work piece. Due to this heat absorption, a rise in the temperature of the work piece occurs and it may result in dimensional inaccuracies, surface damage and deformation [2]. Therefore, it is important to reduce the rise in the work piece temperature during the machining of aluminium alloys. If dry machining is employed then, the cutting temperatures can be reduced by proper selection of cutting parameters and tool geometry.

Optimization of the machining parameters was a topic of extensive research since long. Large numbers of input and output variables are affecting the machining processes. Input variables may include variables like tool material, coatings, tool geometry, cutting speed, feed, and depth of cut, work piece hardness, tensile strength etc. The output variables may include surface roughness, cutting forces, tool wear, cutting power, vibrations; cutting temperature, material removal rate etc. The parameters like cutting temperature, and work piece temperature rise were considered as response variables in some of the recent works.

Tamilarasan et al. [6], have used cutting speed, feed rate, axial depth of cut and radial depth of cut as variables during the end milling of tool steel. The response variables were cutting temperature, tool wear and metal removal rate. It was observed that the cutting temperatures were more influenced by cutting speed and feed per tooth. In another work, Tamilarasan et al. [7, 8] have determined optimum cutting conditions for hard milling. The response variables were cutting temperature, tool wear and MRR. The analysis was carried out using combination of response surface methodology (RSM) and evolutionary optimization techniques. Tamilsaran et al. $[9,10]$ also carried out multi objective optimization of work piece surface temperature, cutting forces and sound pressure level. The material used for this study was $100 \mathrm{MnCrW} 4$ tool steel. The input parameters used for the 
experimentations were work material hardness, nose radius, feed per tooth, radial and axial depth of cut. It was concluded that the most influential parameter was feed, followed by work piece hardness and depth of cut.

Sukumar et al. [11], have carried out experimentation on aluminium metal matrix composite. The surface roughness, cutting force, vibrations and cutting temperature were the response parameters. The cutting speed was identified as the most influential parameter affecting the cutting temperature. Sivasakthivel et al. $[12,13]$, used RSM and genetic algorithm (GA) combination for optimizing the geometrical and process parameters for end milling of $\mathrm{Al}$ alloys. The geometric parameters like helix angle, rake angle and nose radius were used along with machining parameters like speed, feed and depth of cut. Helix angle and rake angles were found to be the most dominating parameters affecting the temperature rise of the work piece. The work piece temperatures were recorded using a K-type thermocouple embedded in a hole drilled in the work piece.

Kadirgama et al. [14], have used RSM and developed first-order temperature model while machining HASTELLOY C-22HS with carbide coated cutting tool. Finite element analysis (FEA) was employed for confirmation of the temperature distribution on cutting tool. Feed rate was found to be the most dominating parameter affecting the cutting temperature, followed by the axial depth and cutting speed. Patel et al. [15], did similar kind of studies using cutting speed, feed rate and axial depth as control factors and work piece temperature as output parameter. The end milling experiments, were carried out on mild steel using carbide cutters. The study reveals that depth of cut is the most significant parameter which affects the work piece temperature. Jayakumar et al. [16], carried out end milling on Al-SiCp by varying cutting speed, feed, depth of cut and volume of $\mathrm{SiC}$ particles. The cutting forces and tool-work interface temperature were recorded and modelled using RSM. The cutting temperatures were found to be increasing with increase in the percentage of $\mathrm{SiC}$ particles.

In the case of other machining operations, R. Çakiroğlu et al. [17], have carried out experimentation for optimization of the cutting parameters for reducing the drill bit temperature during drilling of Al 7075 work piece. The cutting speed, feed rate and cutting tool (uncoated and coated carbide drills) were used as control factors. Taguchi $L_{18}$ orthogonal array was used for determining the settings of cutting parameters. The most significant control factor affecting the drill bit temperature was found to be feed rate. Das et al. [18], have optimized the cutting parameters for reducing tool wear and work piece surface temperature during turning of AISI D2 steel. Cutting speed, feed and depth of cut were used as input factors. Depth of cut and speed were found to be critical factors for reducing the tool wear and work piece temperature. Temperature was used as signal factor, while roughness was used as response factor; speed, feed and depth of cut as the control factors in a work carried out by Suhail et al. [19]. Medium carbon steel was used as material and it was found that feed rate has strong influence on roughness and the depth of cut has strong influence on temperature. 
So, cutting temperature and work piece temperature were used as the response variables. In order to control the temperatures during dry machining proper selection of the cutting and geometrical parameters is needed.

Beside the common input factors like cutting speed, feed and depth of cut, the number of flutes on the milling cutter can be an additional input variable. Yahya [20], had carried out experimentation on Al 6061 alloy with high speed steel end milling cutters having two, three and four flutes. The cutting forces and surface roughness were measured. It was found that numbers of flutes were affecting the surface roughness.

Sarikaya et al. [21], have carried out experiments on milling of AISI 1050 steel by varying depth of cut, feed rate, cutting speed, and number of insert. The responses like vibration signals, cutting force, and surface roughness were measured and feed rate was found to be the most influential factor affecting all the responses.

Erkan et al. [22], have carried out experiments by varying number of flutes, feed, depth of cut and cutting speed during milling of glass fibre reinforced polymer composite (GFRP) materials to obtain the required surface roughness. A decrease in the surface roughness with increasing cutting speed and decreasing feed rate was noticed. Improved surface quality was observed with increasing number of flutes.

Anhai et al. [23], have developed the computer-aided quick design of solid end mill using UG platform. Using finite element simulation, the effect of geometrical parameters of tool such as helix angle, rake angle, and number of flutes on cutting forces and cutting temperature was studied. It was found that the cutting temperature reduces with increase in number of flutes up to 4 flutes and then starts to increase because of availability of less chip flow space. Minimum cutting temperature was observed when a cutter having four number of flutes was used.

From above discussions, it was noticed that the number of flutes affects the surface roughness, vibrations, cutting forces and cutting temperature. Though, the effect of the tool geometry on work piece temperature rise was studied [12, 13], the effect of variation of the number of flutes on work piece temperature rise is not studied yet.

So, in the current work the number of flutes was selected as a control factor along with spindle speed, depth of cut and feed rate. The effect of variation of these control factors on the work piece temperature rise during end milling of $\mathrm{Al} 6063$ alloy was studied experimentally. Taguchi method was used for design and analysis of experiments.

Taguchi method reduces the number of experiments significantly by using orthogonal arrays and also minimizes the effects of factors that cannot be controlled. It gives a easy, disciplined and efficient approach to identify the optimum cutting parameters in the manufacturing process [24]. A well designed set of experiments, in which all parameters of significance are varied over a specified range, is a much better approach to obtain organized data. Such a complete set of experiments gives expected results. The time, material and cost associated with experimenta- 
tion can be reduced using design of experiments (DOE) techniques. Dr. Taguchi has developed a method based on "orthogonal array" experiments that gives much reduced "variance" for the experiment with "optimum settings "of control parameters. Thus, the combination of DOE with optimization of control parameters to obtain optimized results is achieved in the Taguchi method.

Kivak [24] used the Taguchi method for optimizing the surface roughness and flank wear in milling of Hadfield steel. Physical vapour deposition (PVD) and chemical vapour deposition (CVD) coated inserts along with cutting speed and feed rate were selected as control factors. Feed and cutting speed were as found to be the most dominant factors affecting surface roughness and flank wear, respectively. The Taguchi method was used for determination of optimum parameters for getting better surface finish and micro hardness of magnesium alloy for dry end milling. Cutting speed, feed and depth of cut were selected as process parameters and an analysis was carried out using the gray relational arrays. It was noticed that the feed rate is the most leading factor affecting the surface integrity in milling of magnesium alloys [25].

Taguchi-based gray relational arrays were successfully used for optimization of parameters for end milling of Inconel 718 and aluminium alloy 6061 [26, 27]. Process parameters were optimized for improving the surface finish in end milling of different materials like GFRP, AISI 1060, composites, operations using Taguchi method [22, 28-31]. Cutting forces and roughness were used as the performance parameters in optimization of process parameters in end milling of titanium alloy and hardened steel [32]. During this study, it was noticed that depth of cut is the most significant parameter affecting cutting forces and feed is main parameter affecting surface roughness. In a similar study, for AISI H 13 is machined with coated carbide inserts and high cutting speed, low feed and low depth of cut were recommended for better finish and low forces [33]. In another study, by Moshat et al., a principal component analysis (PCA) based Taguchi method was employed for optimization of parameters for CNC end milling for increasing MRR and surface quality [34].

Applications of the Taguchi method are not limited to conventional metal cutting operations. It can also be used effectively in other field. This method was used for the optimization of the kerf width and taper during laser thick foam cutting operation with cutting speed, laser power, frequency, duty cycle, and gas pressure as the control factors [35]. This brief review clearly demonstrates the capabilities of Taguchi method for DOE and optimization of the parameters.

In the current work, the designed experiments were carried out by varying the control factors, like the number of flutes, spindle speed, depth of cut and feed rate. Taguchi $L_{18}$ array was selected for design of experimentation. Signal to noise ratio was used to determine optimal machining conditions of number of flutes, depth of cut, spindle speed and feed rate. ANOVA was employed for determination of significant parameters and regression analysis was used for prediction of work piece temperature rise. 


\section{Details of experiments}

\subsection{Experimental procedure}

The experiments were conducted on AMS make (model tool room) vertical, 3 axes CNC milling machine (Fig. 1) having maximum spindle speed of $6000 \mathrm{rpm}$ and $7.5 \mathrm{~kW}$ drive motor. The work piece material selected was aluminium alloy (Al 6063), a commonly available metal used in automobile and valve industries. The chemical composition of the material is given in Table 1. The dimensions of test specimen were $32 \times 32 \mathrm{~mm}$ in cross section and $40 \mathrm{~mm}$ in length. The work piece dimensions were adopted from the works of Sivasakthivel et al., [12, 13]. A central slot was milled in the work piece during the experimentation. Thus, the radial depth of cut was equal to the cutter diameter.

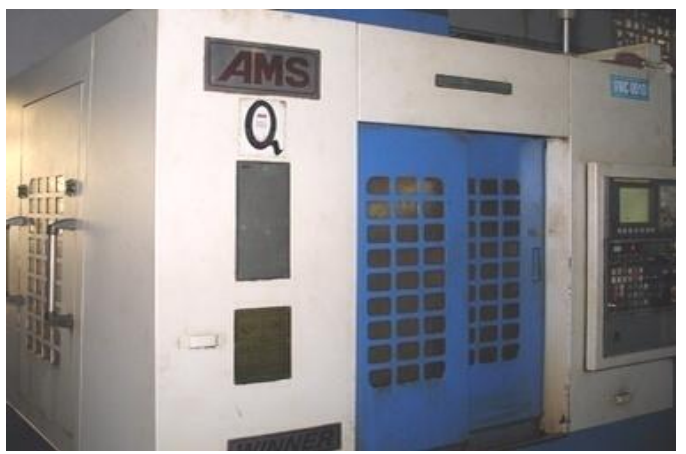

Fig. 1. AMS milling machine

Table 1.

Composition of Al 6063 (chemical, \% wt.)

\begin{tabular}{|c|c|c|c|c|c|c|c|c|}
\hline $\mathrm{Al}$ & $\mathrm{Cr}$ & $\mathrm{Cu}$ & $\mathrm{Fe}$ & $\mathrm{Mg}$ & $\mathrm{Mn}$ & $\mathrm{Si}$ & $\mathrm{Ti}$ & $\mathrm{Zn}$ \\
\hline 96.9 to 97.8 & 0.1 & 0.1 & 0.6 & 0.4 to 0.9 & 0.3 & 0.3 to 0.7 & 0.2 & 0.2 \\
\hline
\end{tabular}

Measuring the temperature during machining is a critical task. In operations like milling and grinding, where the tools are revolving at very high speeds, the task of temperature measurement becomes even more difficult. In the literature, [36-42], variety of methods were suggested and used for the measurement of temperature during machining. Calorimetric method, use of tool-work thermocouples, embedded thermocouples; single wire thermocouple, infrared thermometers, infrared cameras and PVD film were in some of the methods used for measurement of temperature during machining. For operations like grinding and milling, it is recommended to use the thermocouple embedded in the work piece to measure rise in work piece temperature. Richardson et al. [43], have noticed uniform rise of the work piece temperature and thus used one central thermocouple to measure the temperature rise. The similar strategy was used in the current work. Similar to the 
work carried by Sivasakthivel et al. [12, 13], the temperature rise of the work piece was measured by using a K-type thermocouple placed at a distance of $4 \mathrm{~mm}$ below the machining surface. The measuring range of the thermocouple was $-50^{\circ} \mathrm{C}$ to $1300^{\circ} \mathrm{C}$ with accuracy of $0.1^{\circ} \mathrm{C}$. The thermocouple was inserted in a $2 \mathrm{~mm}$ hole drilled in the work piece and it was ensured that the thermocouple will remain at $4 \mathrm{~mm}$ distance from machined surface during each experimental run. Fig. 2 shows the work piece mounted on machine along with the thermocouple wire. Initial temperature of the work piece before machining and maximum temperature of the work piece during the machining were measured. The difference between the initial and maximum temperature was termed as work piece temperature rise $\left(\Delta T^{\circ} \mathrm{C}\right)$.

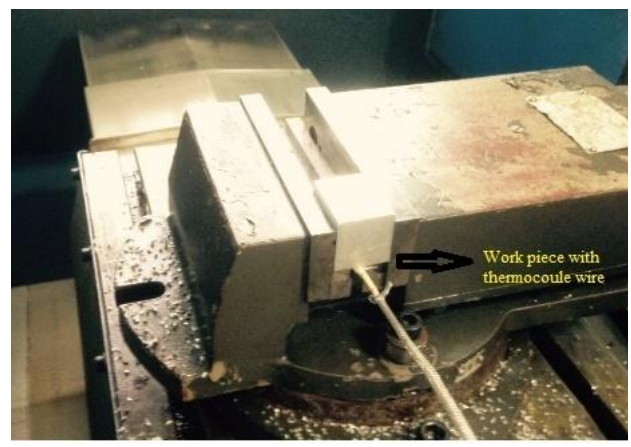

Fig. 2. Work piece mounted on machine with thermocouple

\subsection{Cutting tools and levels of the control factors}

The cutting tool used were high speed steel (HSS) end mill cutters and machining was performed under dry conditions. The tools were supplied by a local manufacturer. Two sets of cutting tools were used, one having 2 flutes and other having 4 flutes. The diameter of the tool was $10 \mathrm{~mm}$. The helix angle and rake angle of the cutter were $45^{\circ}$ and $4^{\circ}$, respectively. The ranges of the control factors and their units were selected with reference to the work carried out by Zhang et al. [31] for Al alloy. The range of the parameters were modified suitably using the machine limitations and the recommendation of tool manufactures. Table 2 shows the details of the levels of the control factors and their units.

Control factors and their levels

\begin{tabular}{|l|c|c|c|c|c|}
\hline Parameters & Designation & Unit & Level 1 & Level 2 & Level 3 \\
\hline Number of flutes & $\mathrm{N}$ & - & 2 & 4 & - \\
\hline Depth of cut & $\mathrm{D}$ & $\mathrm{mm}$ & 0.5 & 1.5 & 2.5 \\
\hline Spindle speed & $\mathrm{S}$ & $\mathrm{m} / \mathrm{min}$ & 2000 & 3000 & 4000 \\
\hline Feed rate & $\mathrm{F}$ & $\mathrm{mm} / \mathrm{min}$ & 20 & 60 & 100 \\
\hline
\end{tabular}




\section{The design of experiments and optimization}

\subsection{Taguchi method and design of experiments}

The Taguchi experimental design method is widely used for design and analysis of experiment and process optimization. Taguchi method was developed using factorial design of experiments and extensively employed for manufacturing domain. The Taguchi design procedure consists of three stages: a. System design, b. Parameter design, and c. Tolerance design. The parameter design is the most important stage [17]. According to the number of levels of the control factors, the most appropriate mixed orthogonal array $L_{18}\left(2^{1} \times 3^{3}\right)$ was selected for the present work. The $L_{18}$ array used for experiments is shown in Table 3.

Table 3.

Experimental design with $L_{18}$ array

\begin{tabular}{|r|c|c|c|c|}
\hline Run & $\mathrm{N}$ & $\mathrm{D}$ & $\mathrm{S}$ & $\mathrm{F}$ \\
\hline 1 & 1 & 1 & 1 & 1 \\
\hline 2 & 1 & 1 & 2 & 2 \\
\hline 3 & 1 & 1 & 3 & 3 \\
\hline 4 & 1 & 2 & 1 & 1 \\
\hline 5 & 1 & 2 & 2 & 2 \\
\hline 6 & 1 & 2 & 3 & 3 \\
\hline 7 & 1 & 3 & 1 & 2 \\
\hline 8 & 1 & 3 & 2 & 3 \\
\hline 9 & 1 & 3 & 3 & 1 \\
\hline
\end{tabular}

\begin{tabular}{|r|c|c|c|c|}
\hline Run & $\mathrm{N}$ & $\mathrm{D}$ & $\mathrm{S}$ & $\mathrm{F}$ \\
\hline 10 & 2 & 1 & 1 & 3 \\
\hline 11 & 2 & 1 & 2 & 1 \\
\hline 12 & 2 & 1 & 3 & 2 \\
\hline 13 & 2 & 2 & 1 & 2 \\
\hline 14 & 2 & 2 & 2 & 3 \\
\hline 15 & 2 & 2 & 3 & 1 \\
\hline 16 & 2 & 3 & 1 & 3 \\
\hline 17 & 2 & 3 & 2 & 1 \\
\hline 18 & 2 & 3 & 3 & 2 \\
\hline
\end{tabular}

The Taguchi method uses a loss function to find the difference between experimental and desired values. The loss function is further converted to signal to noise $(\mathrm{S} / \mathrm{N})$ ratio $(\eta)[24]$. The term signal means the required value and term noise means the non required value, thus, $\mathrm{S} / \mathrm{N}$ ratio gives the dispersion in the region of the required value $[44,45]$. The aim of the current work was minimization of temperature rise of work piece during end milling. So, out of the three quality characteristics (the lower-the-better, the higher-the-better and the nominal-the-better), the lower-the-better was used. For this, the $\mathrm{S} / \mathrm{N}$ ratio is defined in Taguchi method as:

$$
\eta=-10 \log \left(\frac{1}{n} \sum_{i=1}^{n} y_{i}^{2}\right)
$$

where $\eta$ is $\mathrm{S} / \mathrm{N}$ ratio in $\mathrm{dB}, y_{i}$ is the observed data in $i^{\text {th }}$ experiment and $n$ is the number of repetitions in the trial [24]. 


\section{Results and discussions}

\subsection{Analysis of $S / N$ ratio}

The experiments were conducted according to the plan and the work piece temperature rise $(\Delta T)$ was recorded. The analysis was carried out using MINITAB V-17 statistical software package. In order to achieve the goal of minimization of, the $\mathrm{S} / \mathrm{N}$ ratios were calculated by using eq. (1). Table 4 shows the experimental results and the corresponding values of $\mathrm{S} / \mathrm{N}$ ratios in $\mathrm{dB}$. It can be noticed that the measured values of $\Delta T$ were small, as the thermocouple was mounted $4 \mathrm{~mm}$ below the surface to be machined.

Table 4.

Experimental results and $\mathrm{S} / \mathrm{N}$ ratio values

\begin{tabular}{|c|c|c|c|c|c|c|}
\hline $\begin{array}{c}\text { Expt. } \\
\text { number }\end{array}$ & $\begin{array}{c}\text { Number } \\
\text { of flutes } \\
(\mathrm{N})\end{array}$ & $\begin{array}{c}\text { Depth } \\
\text { of cut } \\
(\mathrm{D}) \mathrm{mm}\end{array}$ & $\begin{array}{c}\text { Spindle } \\
\text { speed } \\
(\mathrm{S}) \mathrm{rpm}\end{array}$ & $\begin{array}{c}\text { Feed rate } \\
(\mathrm{F}) \\
(\mathrm{F}) \mathrm{mm} / \mathrm{min}\end{array}$ & $\begin{array}{c}\text { Temperature } \\
\text { rise } \\
(\Delta T){ }^{\circ} \mathrm{C}\end{array}$ & $\begin{array}{c}\text { S/N } \\
\text { ratio } \\
(\mathrm{dB})\end{array}$ \\
\hline 1 & 2 & 0.5 & 2000 & 20 & 3.1 & -9.82723 \\
\hline 2 & 2 & 0.5 & 3000 & 60 & 3.6 & -11.1261 \\
\hline 3 & 2 & 0.5 & 4000 & 100 & 3.9 & -11.8213 \\
\hline 4 & 2 & 1.5 & 2000 & 20 & 5.4 & -14.6479 \\
\hline 5 & 2 & 1.5 & 3000 & 60 & 6.4 & -16.1236 \\
\hline 6 & 2 & 1.5 & 4000 & 100 & 7.0 & -16.9020 \\
\hline 7 & 2 & 2.5 & 2000 & 60 & 9.7 & -19.7354 \\
\hline 8 & 2 & 2.5 & 3000 & 100 & 8.5 & -18.5884 \\
\hline 9 & 2 & 2.5 & 4000 & 20 & 12.2 & -21.7272 \\
\hline 10 & 4 & 0.5 & 2000 & 100 & 2.9 & -9.24796 \\
\hline 11 & 4 & 0.5 & 3000 & 20 & 3.4 & -10.6296 \\
\hline 12 & 4 & 0.5 & 4000 & 60 & 5.0 & -13.9794 \\
\hline 13 & 4 & 1.5 & 2000 & 60 & 5.3 & -14.4855 \\
\hline 14 & 4 & 1.5 & 3000 & 100 & 5.5 & -14.8073 \\
\hline 15 & 4 & 1.5 & 4000 & 20 & 8.4 & -18.4856 \\
\hline 16 & 4 & 2.5 & 2000 & 100 & 9.0 & -19.0849 \\
\hline 17 & 4 & 2.5 & 3000 & 20 & 12.1 & -21.6557 \\
\hline 18 & 4 & 2.5 & 4000 & 60 & 14.6 & -23.2871 \\
\hline
\end{tabular}

The effect of variation of the control factors on $\Delta T$ was analyzed using the $\mathrm{S} / \mathrm{N}$ response table (Table 5) obtained by using the Taguchi method. In this table, the value of delta $(\Delta)$ was maximum $(\Delta=9.59)$ for depth of cut, followed by spindle speed $(\Delta=3.2)$, feed $(\Delta=1.38)$ and number of flutes $(\Delta=0.57)$. The higher value of $\Delta$ for a particular control factor indicates significant effect of variation of that factor on work piece temperature rise. So, in the current range of the control factors the depth of cut was the most significant variable affecting the work piece 
Table 5.

Response table for $\mathrm{S} / \mathrm{N}$ ratio

\begin{tabular}{|c|c|c|c|c|}
\hline Level & $\begin{array}{c}\text { Number } \\
\text { of flutes }\end{array}$ & $\begin{array}{c}\text { Depth } \\
\text { of cut }\end{array}$ & $\begin{array}{c}\text { Spindle } \\
\text { speed }\end{array}$ & Feed rate \\
\hline 1 & -15.61 & -11.11 & -14.5 & -16.16 \\
\hline 2 & -16.18 & -15.91 & -15.49 & -16.46 \\
\hline 3 & & -20.68 & -17.7 & -15.08 \\
\hline Delta $(\Delta)$ & 0.57 & 9.57 & 3.2 & 1.38 \\
\hline Rank & 4 & 1 & 2 & 3 \\
\hline
\end{tabular}

temperature rise and number of flutes was the least significant control factor. Thus, number of flutes was ranked fourth while the rank of depth of cut was one. The main effects plot of the analysis, which shows the graphical representation of the information in Table 5, is shown in Fig. 3. Best level of the control factors for minimizing the work piece temperature rise can be determined from this figure. The highest value of the $\mathrm{S} / \mathrm{N}$ ratio was used as a criterion to determine the best level for each control factor. The values of these control factors and the corresponding $\mathrm{S} / \mathrm{N}$ ratios are given in Table 6 . The levels of factors giving minimum temperature rise values were specified as factor $\mathrm{N}$ (level 1), factor D (level 1), factor S (level 1 ) and factor $\mathrm{F}$ (level 3 ). So, the minimum work piece temperature rise $(\Delta T)$ can be obtained with two fluted end milling cutter at $0.5 \mathrm{~mm}$ depth of cut, $2000 \mathrm{rpm}$ spindle speed and $100 \mathrm{~mm} / \mathrm{min}$ feed rate. The value of $\Delta$ was very small for the number of flutes, so four fluted tool can also be used without affecting the work piece temperature rise. In section 4.3, this point is discussed in more details.

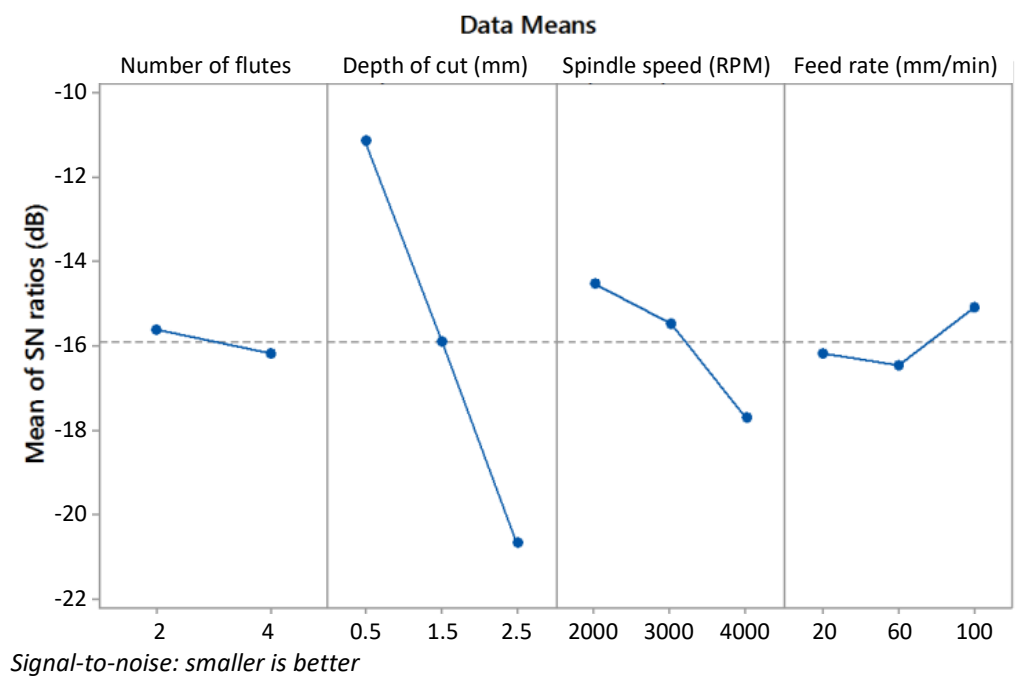

Fig. 3. Main effects plot for $\mathrm{S} / \mathrm{N}$ ratio 
Best level of control factors

\begin{tabular}{|c|c|c|c|c|}
\hline Symbol & Parameter & $\begin{array}{c}\text { Best } \\
\text { level }\end{array}$ & $\begin{array}{c}\text { Corresponding } \\
\text { value of factor }\end{array}$ & $\begin{array}{c}\text { S/N ratio } \\
(\mathrm{dB})\end{array}$ \\
\hline N & Number of flutes & 1 & 2 flutes & -15.61 \\
\hline D & Depth of cut & 1 & $0.5 \mathrm{~mm}$ & -11.11 \\
\hline S & Spindle speed & 1 & $2000 \mathrm{rpm}$ & -14.5 \\
\hline F & Feed rate & 3 & $100 \mathrm{~mm} / \mathrm{min}$ & -15.08 \\
\hline
\end{tabular}

\subsection{ANOVA analysis}

ANOVA is a powerful computational technique used for determination of the impact of each control factor on the observed response [45]. In this study, ANOVA was used to analyse the effects of control factors on the temperature rise. The analysis was carried out for $95 \%$ confidence level. The results of ANOVA are shown in Table 7. The F factors for each control factor were compared. The last column of the table shows the percent contribution ratio (PCR). The PCR is calculated by using equation:

$$
\mathrm{PRC}=\left(\frac{S S n-V e \cdot V n}{S S t}\right) \cdot 100
$$

where $S S n$ is sum of squares for parameter $\mathrm{N}, V e$ is variance of error and $V n$ is the degree of freedom for parameter N and SSt is total sum of squares. The PCR for depth of cut was found to be $86.217 \%$, which is the highest among all the values. It indicates that depth of cut is the most significant parameter followed by spindle speed $(\mathrm{PCR}=9.8944)$ and feed $(\mathrm{PCR}=1.7894)$ and number of flutes $(\mathrm{PCR}=0.3626)$. Thus, it can be noticed that the ANOVA results are complimenting the results obtained from $\mathrm{S} / \mathrm{N}$ ratio analysis.

Table 7.

Analysis of variance for $\mathrm{S} / \mathrm{N}$ ratios

\begin{tabular}{|c|c|c|c|c|c|c|c|}
\hline Source & DF & Seq. SS & Adj. SS & Adj. MS & F & P & PCR \\
\hline Number of Flutes & 1 & 1.481 & 1.481 & 1.481 & 4.54 & 0.059 & 0.3626 \\
\hline Depth of cut & 2 & 275.015 & 275.015 & 137.508 & 421.02 & 0 & 86.217 \\
\hline Spindle speed & 2 & 32.145 & 32.145 & 16.072 & 49.21 & 0 & 9.8944 \\
\hline Feed rate & 2 & 6.349 & 6.349 & 3.175 & 9.72 & 0.005 & 1.7894 \\
\hline Residual error & 10 & 3.266 & 3.266 & 0.327 & & & \\
\hline Total & 17 & 318.257 & & & & & \\
\hline
\end{tabular}


Table 8

Response table for means

\begin{tabular}{|c|c|c|c|c|}
\hline Level & $\begin{array}{c}\text { Number } \\
\text { of flutes }\end{array}$ & $\begin{array}{c}\text { Depth } \\
\text { of cut }\end{array}$ & $\begin{array}{c}\text { Spindle } \\
\text { speed }\end{array}$ & Feed rate \\
\hline 1 & 6.644 & $\mathbf{3 . 6 5}$ & $\mathbf{5 . 9}$ & 7.433 \\
\hline 2 & 7.356 & 6.333 & 6.583 & 7.433 \\
\hline 3 & & 11.017 & 8.517 & 6.133 \\
\hline Delta & 0.711 & 7.367 & 2.617 & 1.3 \\
\hline Rank & 4 & 1 & 2 & 3 \\
\hline
\end{tabular}

\subsection{Evaluation of the experimental results}

The surface plot of work piece temperature rise $(\Delta T)$ vs. number of flutes and spindle speed was obtained by using the MINITAB V-17 software package and is shown in Fig. 4. The figure clearly shows that the effect of number of flutes on $\Delta T$ was not significant. The $\Delta T$ increased with increase in spindle speed, like the results obtained by Sivasakthivel et al. $[12,13]$. The maximum rise in the work piece temperature was noticed for the 4 fluted tool with $4000 \mathrm{rpm}$ spindle speed.

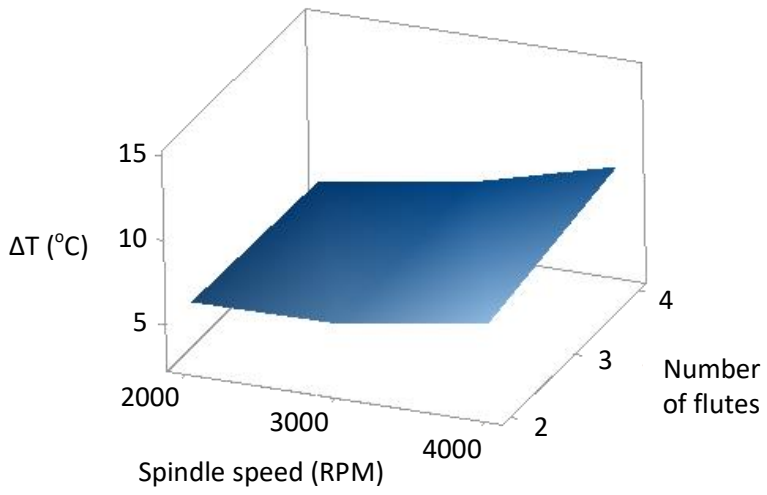

Fig. 4. Surface plot of $\Delta T$ vs. number of flutes and spindle speed

The surface plot of work piece temperature rise vs. number of flutes and feed indicates reduction in $\Delta T$ with increase in the feed for 4 fluted tool, whereas, $\Delta T$ was almost constant for 2 fluted tool (Fig. 5). The results of the two fluted tool were similar to the results obtained by Patel et al. [15]. The maximum rise in the temperature was observed for 4 fluted tool with feed rate of $60 \mathrm{~mm} / \mathrm{min}$. For higher feed rate $(100 \mathrm{~mm} / \mathrm{min})$ the temperature rise was found to be reduced. Fig. 6 shows the variation in $\Delta T$ with depth of cut. As the depth of cut was increasing the $\Delta T$ was also increasing. The higher temperature rise was noticed for 4 fluted tool with $2.5 \mathrm{~mm}$ depth of cut. In this case, also the effect of number of flutes was found to be negligible. The current results were similar to the results obtained in the previous 
works by Sivasakthivel et al. [12,13] and Patel et al. [15]. In these previous works the number of flute was not used as the control factor. Although, it was found that this new control factor does not contribute to the work piece temperature rise much, it is important structural parameter which decides the rigidity of the tool. For same diameter end mill more number of flutes gives better tool rigidity by increasing the diameter of the core of the cutter [23]. So, it is recommended to use four fluted end milling cutter for slot milling of the $\mathrm{Al}$ alloy. It was observed that the most critical parameter affecting the temperature rise was depth of cut and the lowest value of the depth of is desirable to reduce the value of $\Delta T$. As the depth of cut is normally selected by the process engineers based on their experience and using the machining manuals, so it is easy to control. The current results can help in selection of the depth of cut along with the spindle speed and feed rate in order to reduce the work piece temperature rise.

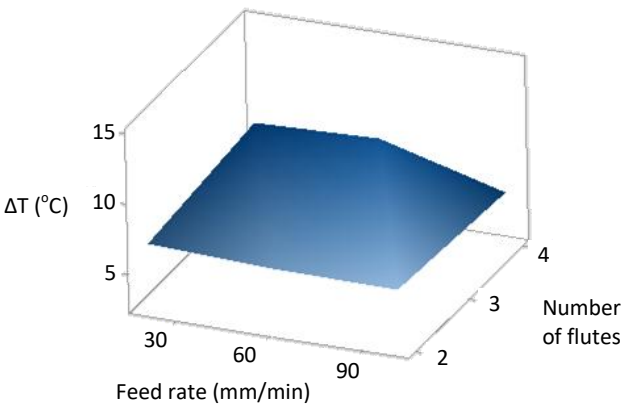

Fig. 5. Surface plot of $\Delta T$ vs. number of flutes and feed rate

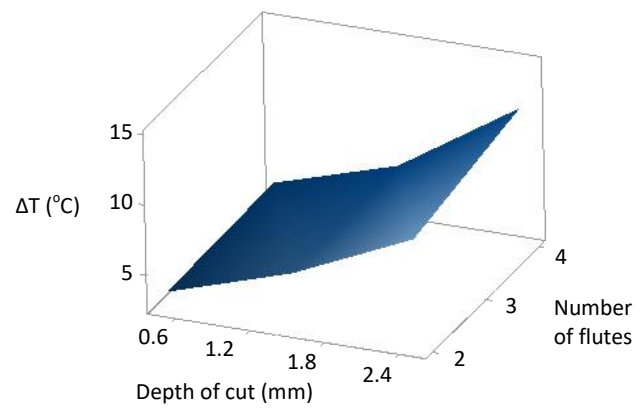

Fig. 6. Surface plot of $\Delta T$ vs. number of flutes and depth of cut

\subsection{Regression analysis}

To find out the relationship between the control factors and work piece temperature rise, regression analysis was used. The multiple regression analysis was carried out using MINITAB V-17 software package. The quadratic predictive equation for work piece temperature rise is given below:

$$
\Delta T_{p}=0.11+0.68 \mathrm{D}+0.001308 \mathrm{~S}-0.01625 \mathrm{~F}+1.000 \mathrm{D}^{2}
$$

where: $\mathrm{D}$ - depth of cut, $\mathrm{S}$ - spindle speed, $\mathrm{F}$ - feed rate and $\Delta T_{p}$ - predicted value of temperature rise.

The $\mathrm{R}^{2}$ value signifies the accuracy of fitting the data by regression equation. The $\mathrm{R}^{2}$ value of the regression equation developed, was found to be 0.940 , which indicates the close match between the measured and predicted data. Fig. 7 
shows the comparison of predicted temperature rise $\left({ }^{\circ} \mathrm{C}\right)$ and measured temperature rise $\left({ }^{\circ} \mathrm{C}\right)$.

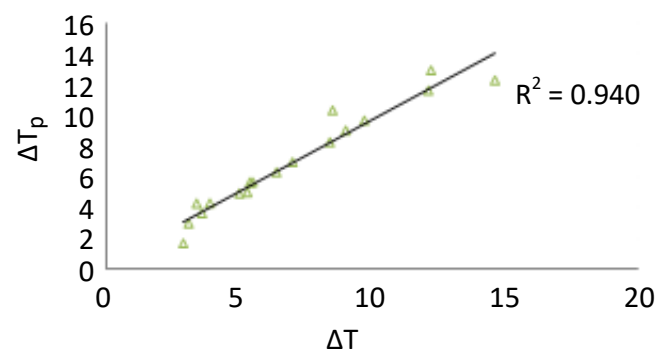

Fig. 7. Predicted vs. measured temperature rise (both in ${ }^{\circ} \mathrm{C}$ ) in work piece temperature

\subsection{Confirmation test}

In the Taguchi optimization technique, a confirmation experiment is required to be conducted for the validation of the optimized conditions. For the estimation of optimum temperature rise following equation was used:

$$
T_{\mathrm{opt}}=\left(\mathrm{D}_{1}-\mathrm{T}_{\mathrm{T}}\right)+\left(\mathrm{S}_{1}-\mathrm{T}_{\mathrm{T}}\right)+\mathrm{T}_{\mathrm{T}}
$$

where $D_{1}$ and $S_{1}$ represent the optimum mean values of the temperature rise for the most significant parameters, depth of cut and spindle speed. These values are shown in bold letters in Table 8. $\left(\mathrm{D}_{1}=3.650\right.$ and $\left.\mathrm{S}_{1}=5.9\right)$. The other two parameters were less significant, so they were ignored.

$\mathrm{T}_{\mathrm{T}}$ is average of all the temperature rise values $\left(\mathrm{T}_{\mathrm{T}}=7\right)$. Using the above equation, $T_{\mathrm{opt}}$ was calculated as $2.55^{\circ} \mathrm{C}$. In order to confirm the accuracy by means of which the system had realised the optimization, the following equations were used for calculating confidence interval (CI).

$$
\begin{gathered}
\mathrm{CI}=\sqrt{\mathrm{F}_{\alpha, 1, \mathrm{fe}} V e\left[\frac{1}{n_{\text {eff }}}+\frac{1}{\mathrm{R}}\right]} \\
n_{\text {eff }}=\frac{1}{1+\text { Tdof }}
\end{gathered}
$$

where, $\mathrm{F}_{\alpha, 1, \text { fe }}$ is $\mathrm{F}$ ratio at $95 \%$ confidence level, $\alpha$ is significance level and fe is DOF for error. In current work $\alpha=0.05, \mathrm{fe}=10$ and from $\mathrm{F}$ distribution table, $\mathrm{F}_{0.05,1,10}=4.96$. Also, $V e$ is variance of error $(V e=0.327$ from Table 7$) . \mathrm{N}$ is total number of experiment $(\mathrm{N}=18)$ and $\mathrm{R}$ is replications for combinations and experiments $(\mathrm{R}=2)$. Tdof is the total degree of freedom for significant factors (Tdof $=4)$. Using equation (6), $n_{\text {eff }}$ was found to be 3.6 and using equation (5), CI was calculated as 1.12 . 
Then estimated average optimal temperature rise with the $\mathrm{CI}$ at $95 \%$ confidence is:

$$
\begin{aligned}
\left(T_{\mathrm{opt}}-\mathrm{CI}\right) & <T_{\exp }<\left(T_{\mathrm{opt}}+\mathrm{CI}\right) \\
(2.55-1.22) & <T_{\exp }<(2.55+1.22) \\
1.43 & <T_{\exp }<3.67 \\
1.43 & <2.85<3.67
\end{aligned}
$$

The confirmation experiments were carried out and it was found that rise in temperature obtained experimentally within confidence interval limit thus, the optimization for temperature rise in Taguchi method was achieved at a significance level of 0.05 .

\section{Conclusions}

In this study, Taguchi method was successfully employed for determination optimum values of control factors for end milling of Al-6063 under dry conditions. The experimental results were analysed using Taguchi's $\mathrm{S} / \mathrm{N}$ ratio analysis and ANOVA.

The following conclusions can be drawn:

1. Optimum levels of control factors for minimizing the work piece temperature rise were determined. The optimum levels were found to N1, D1, S1 and F3 (i.e., 2 fluted tool with $0.5 \mathrm{~mm}$ depth of cut, $2000 \mathrm{rpm}$ spindle speed and $100 \mathrm{~mm} / \mathrm{min}$ feed rate). It means low spindle speed, low depth of cut and high feed rate are favourable conditions to achieve minimum rise in work piece temperature.

2. The number of flutes on the cutter was a new parameter included in this study. It was found that the effect of this factor is not significant on the work piece temperature rise. It is recommended to use four fluted tool instead of two fluted tool for slot milling of Al-6063 as this tool gives better rigidity without contributing much to the work piece temperature.

3. The statistical analysis shows that the depth of cut was the most significant control factor affecting the work piece temperature rise with the percentage contribution of $86.217 \%$ and it was followed by spindle speed with percentage contribution of $9.89 \%$. The other two factors feed rate and number of flutes were found to be statistically insignificant.

4. The multiple quadratic regression equation has high correlation coefficient of 0.94 , which indicates excellent relationship between the predicted and measured values of the work piece temperature rise.

5. The confirmation test result shows that the measured values were within $95 \%$ confidence level. 
The results obtained showed the reliability of Taguchi method for the reduction of work piece temperature rise during milling of $\mathrm{Al}$ alloy. In the future, these results may be useful for academic research and industrial applications. Future studies could consider the effects of other factors such as the tool diameter, coating materials, cutting tool materials, hardness of work piece material, thermal properties of tool / work piece materials and lubricants, all of which affect the work piece temperature rise. The future study may also include the interaction effects of the control factors.

Manuscript received by Editorial Board, October 02, 2016; final version, April 29, 2017.

\section{References}

[1] M.T. Hayajneh, M.S. Tahat, and J. Bluhm. A study of the effects of machining parameters on the surface roughness in the end-milling process. Jordan Journal of Mechanical and Industrial Engineering, 1(1):1-5, 2007.

[2] P.S. Sreejith and B.K.A. Ngoi. Dry machining: Machining of the future. Journal of Materials Processing Technology, 101(1-3):287-291, 2000. doi: 10.1016/S0924-0136(00)00445-3.

[3] V.P. Astakhov. Improvements of tribological conditions. In V.P. Astakhov, editor, Tribology of metal cutting, pages 326-390. Elsevier, 2006.

[4] A. Shokrani, V. Dhokia, and S.T. Newman. Environmentally conscious machining of difficultto-machine materials with regard to cutting fluids. International Journal of Machine Tools and Manufacture, 57:83-101, June 2012. doi: 10.1016/j.jmachtools.2012.02.002.

[5] V.P. Astakhov. Ecological machining: Near-dry machining. In J.P. Davim, editor, Machining: fundamentals and recent advances, pages 195-223. Springer Verlag, London, 2008.

[6] A. Tamilarasan, K. Marimuthu, and A. Renugambal. Investigations and optimization for hard milling process parameters using hybrid method of RSM and NSGA-II. Rev. Téc. Ing. Univ. Zulia, 39(1):41-54, 2016.

[7] A. Tamilarasan, D. Rajamani, and A. Renugambal. An approach on fuzzy and regression modeling for hard milling process. Applied Mechanics \& Materials, 813/814:498-504, 2015.

[8] A. Tamilarasan and D. Rajamani. Multi-objective optimization of hard milling process using evolutionary computation techniques. International Journal of Advanced Engineering Research and Applications, 1(7):264-275, 2015.

[9] A. Tamilarasan and K. Marimuthu. Multi-response optimization of hard milling process: RSM coupled with grey relational analysis. International Journal of Engineering and Technology, 5(6):4901-4913, 2014.

[10] A. Tamilarasan and K. Marimuthu. Multi-response optimisation of hard milling process parameters based on integrated Box-Behnken design with desirability function approach. International Journal of Machining and Machinability of Materials, 15(3-4):300-320, 2014.

[11] M.S. Sukumar, B.V.S. Reddy, and P. Venkataramaiah. Analysis on multi responses in face milling of AMMC using Fuzzy-Taguchi method. Journal of Minerals and Materials Characterization and Engineering, 3(4):255-270, 2015. doi: 10.4236/jmmce.2015.34028.

[12] M. Santhanakrishnan, P.S. Sivasakthivel, and R. Sudhakaran. Modeling of geometrical and machining parameters on temperature rise while machining $\mathrm{Al} 6351$ using response surface methodology and genetic algorithm. Journal of the Brazilian Society of Mechanical Sciences and Engineering, 39(2):487-496, 2017. doi: 10.1007/s40430-015-0378-5. 
[13] P. Sivasakthivel and R. Sudhakaran. Optimization of machining parameters on temperature rise in end milling of $\mathrm{Al} 6063$ using response surface methodology and genetic algorithm. International Journal of Advanced Manufacturing Technology, 67(9):2313-2323, 2013. doi: 10.1007/s00170-012-4652-8.

[14] K. Kadirgama, M.M. Noor, M.M. Rahman, W.S.W. Harun, and C.H.C. Haron. Finite element analysis and statistical method to determine temperature distribution on cutting tool in endmilling. European Journal of Scientific Research, 30(3):451-463, 2009.

[15] B. Patel, H. Nayak, K. Araniya, and G. Champaneri. Parametric optimization of temperature during CNC end milling of mild steel using RSM. International Journal of Engineering Research \& Technology, 3(1):69-73, 2014.

[16] K. Jayakumar, J. Mathew, and M.A. Joseph. An investigation of cutting force and tool-work interface temperature in milling of $\mathrm{Al}-\mathrm{SiC}_{p}$ metal matrix composite. Proceedings of the Institution of Mechanical Engineers, Part B: Journal of Engineering Manufacture, 227(3):362374, 2013. doi: 10.1177/0954405412472887.

[17] R. Çakıroğlu and A. Acır. Optimization of cutting parameters on drill bit temperature in drilling by Taguchi method. Measurement, 46(9):3525-3531, 2013. doi: 10.1016/j.measurement.2013.06.046.

[18] S.R. Das, R.P. Nayak, and D. Dhupal. Optimization of cutting parameters on tool wear and workpiece surface temperature in turning of AISI D2 steel. International Journal of Lean Thinking, 3(2):140-156, 2012.

[19] A.H. Suhail, N. Ismail, S.V. Wong, and N.A.A. Jalil. Optimization of cutting parameters based on surface roughness and assistance of workpiece surface temperature in turning process. American Journal of Engineering and Applied Sciences, 3(1):102-108, 2010.

[20] Elssawi Yahya, Guofu Ding, and Shengfeng Qin. Prediction of cutting force and surface roughness using Taguchi technique for aluminum alloy AA6061. Australian Journal of Mechanical Engineering, 14(3):151-160, 2016. doi: 10.1080/14484846.2015.1093220.

[21] M. Sarıkaya, V. Y1lmaz, and H. Dilipak. Modeling and multi-response optimization of milling characteristics based on Taguchi and gray relational analysis. Proceedings of the Institution of Mechanical Engineers, Part B: Journal of Engineering Manufacture, 230(6):1049-1065, 2016. doi: 10.1177/0954405414565136.

[22] Ö. Erkan, M. Demetgül, B. Işik, and İ.Nur Tansel. Selection of optimal machining conditions for the composite materials by using Taguchi and GONNs. Measurement, 48:306-313, Feb. 2014. doi: 10.1016/j.measurement.2013.11.011.

[23] A. Li, J. Zhao, Z. Pei, and N. Zhu. Simulation-based solid carbide end mill design and geometry optimization. International Journal of Advanced Manufacturing Technology, 71(9-12):18891900, 2014. doi: 10.1007/s00170-014-5638-5.

[24] T. Kivak. Optimization of surface roughness and flank wear using the Taguchi method in milling of Hadfield steel with PVD and CVD coated inserts. Measurement, 50:19-28, April 2014. doi: 10.1016/j.measurement.2013.12.017.

[25] K. Shi, D. Zhang, and J. Ren. Optimization of process parameters for surface roughness and microhardness in dry milling of magnesium alloy using Taguchi with grey relational analysis. The International Journal of Advanced Manufacturing Technology, 81(1-4):645-651, 2015. doi: 10.1007/s00170-015-7218-8.

[26] L.M. Maiyar, R. Ramanujam, K. Venkatesan, and J. Jerald. Optimization of machining parameters for end milling of Inconel 718 super alloy using Taguchi based grey relational analysis. Procedia Engineering, 64:1276-1282, 2013. doi: 10.1016/j.proeng.2013.09.208.

[27] C.C. Tsao. Grey-Taguchi method to optimize the milling parameters of aluminum alloy. The International Journal of Advanced Manufacturing Technology, 40(1):41-48, 2009. doi: 10.1007/s00170-007-1314-3. 
[28] M.S. Shahrom, N.M. Yahya, and A.R. Yusoff. Taguchi method approach on effect of lubrication condition on surface roughness in milling operation. Procedia Engineering, 53:594-599, 2013. doi: 10.1016/j.proeng.2013.02.076.

[29] R. Sreenivasulu. Optimization of surface roughness and delamination damage of GFRP composite material in end milling using Taguchi design method and artificial neural network. Procedia Engineering, 64:785-794, 2013. doi: 10.1016/j.proeng.2013.09.154.

[30] J.S. Pang, M.N.M. Ansari, O.S. Zaroog, M.H. Ali, and S.M. Sapuan. Taguchi design optimization of machining parameters on the $\mathrm{CNC}$ end milling process of halloysite nanotube with aluminium reinforced epoxy matrix (HNT/Al/Ep) hybrid composite. HBRC Journal, 10(2):138-144, 2014. doi: 10.1016/j.hbrcj.2013.09.007.

[31] J.Z. Zhang, J.C. Chen, and E.D. Kirby. Surface roughness optimization in an end-milling operation using the Taguchi design method. Journal of Materials Processing Technology, 184(1):233-239, 2007. doi: 10.1016/j.jmatprotec.2006.11.029.

[32] S. Vijay and V. Krishnaraj. Machining parameters optimization in end milling of Ti-6Al-4V. Procedia Engineering, 64:1079-1088, 2013. doi: 10.1016/j.proeng.2013.09.186.

[33] J.A. Ghani, I.A. Choudhury, and H.H. Hassan. Application of Taguchi method in the optimization of end milling parameters. Journal of Materials Processing Technology, 145(1):84-92, 2004. doi: 10.1016/S0924-0136(03)00865-3.

[34] S. Moshat, S. Datta, A. Bandyopadhyay, and P. Pal. Optimization of CNC end milling process parameters using PCA-based Taguchi method. International Journal of Engineering, Science and Technology, 2(1):95-102, 2010. doi: 10.4314/ijest.v2i1.59096.

[35] S. Sivarao, M. Robert, and A.R. Samsudin. Taguchi modeling and optimization of laser processing in machining of substantial industrial PVC foam. International Journal of Applied Engineering Research, 8(12):1415-1426, 2013.

[36] M.B. da Silva and J. Wallbank. Cutting temperature: prediction and measurement methods - a review. Journal of Materials Processing Technology, 88(1-3):195-202, 1999. doi: 10.1016/S0924-0136(98)00395-1.

[37] R. Komanduri and Z.B. Hou. A review of the experimental techniques for the measurement of heat and temperatures generated in some manufacturing processes and tribology. Tribology International, 34(10):653-682, 2001. doi: 10.1016/S0301-679X(01)00068-8.

[38] N.A. Abukhshim, P.T. Mativenga, and M.A. Sheikh. Heat generation and temperature prediction in metal cutting: A review and implications for high speed machining. International Journal of Machine Tools and Manufacture, 46(7-8):782-800, 2006. doi: 10.1016/j.ijmachtools.2005.07.024.

[39] D. O'Sullivan and M. Cotterell. Workpiece temperature measurement in machining. Proceedings of the Institution of Mechanical Engineers, Part B: Journal of Engineering Manufacture, 216(1):135-139, 2002. doi: 10.1243/0954405021519645.

[40] J.M. Longbottom and J.D. Lanham. Cutting temperature measurement while machining - a review. Aircraft Engineering and Aerospace Technology, 77(2):122-130, 2005. doi: $10.1108 / 00022660510585956$.

[41] A. Goyal, S. Dhiman, S. Kumar, and R. Sharma. A study of experimental temperature measuring techniques used in metal cutting. Jordan Journal of Mechanical and Industrial Engineering, 8(2):82-93, 2014.

[42] P.J.T. Conradie, G.A. Oosthuizen, N.F. Treurnicht, and A. Al Shaalane. Overview of work piece temperature measurement techniques for machining of Ti6A14V. South African Journal of Industrial Engineering, 23(2):116-130, 2012.

[43] D.J. Richardson, M.A. Keavey, and F. Dailami. Modelling of cutting induced workpiece temperatures for dry milling. International Journal of Machine Tools and Manufacture, 46(10):11391145, 2006. doi: 10.1016/j.ijmachtools.2005.08.008. 
[44] O. Rostam, M.F. Dimin, H.H. Luqman, M.R. Said, L.K. Keong, M.Y. Norazlina, M. Norhidayah, and A. Shaaban. Assessing the significance of rate and time pulse spraying in top spray granulation of urea fertilizer using Taguchi method. 761:308-312, 2015.

[45] S. Sivarao, K.R. Milkey, A.R. Samsudin, A.K. Dubey, and Kidd P. Comparison between Taguchi method and response surface. Jordan Journal of Mechanical and Industrial Engineering, 8(1):35-42, 2014. 